\title{
Analysis of the Relationship Between the Academic Self-Efficacy and Leisure Satisfaction Levels of University Students
}

\author{
Fatih Yaşartürk \\ Correspondence: Fatih Yaşartürk, School of Physical Education and Sport, Bartın University, Bartın, Turkey. \\ Received: January 26, 2019 \\ Accepted: February 10, $2019 \quad$ Online Published: February 13, 2019 \\ doi:10.11114/jets.v7i3.3988 \\ URL: https://doi.org/10.11114/jets.v7i3.3988
}

\begin{abstract}
The aim of this study is to analyze the academic self-efficacy and leisure satisfaction levels of university students according to some variables and to determine the relationship between them. 1053 (642 male and 411 female) students from the Physical Education and Sports College of Bartın University participated in the study. A personal information form prepared by the researchers, the "Academic Self-Efficacy Scale" (ASES) developed by Owen \& Froman (1988) and adapted to Turkish by Ekici (2012) and the "Leisure Satisfaction Scale (LSS)" developed by Beard \& Ragheb (1980) and adapted to Turkish by Gökçe \& Orhan (2011) were used as data collection tools. Descriptive statistical methods, the $\mathrm{t}$-Test, ANOVA and Pearson Correlation tests were used in the analysis of the data. In the findings of the study, it was found that there was a significant difference between the "Social status", "Cognitive Practices", "Technical Skills" and LSS "Social" subscales in terms of the "gender" variable ( $\mathrm{p}<0.05)$, and the result was in favor of the female students. In the correlation test results, it was found that there was a significant relationship in the ASES subscale "Technical Skills" in terms of the "age" variable ( $\mathrm{p}<0.05)$, and the ability to perform technical skills increased as age increased. In addition, a significant relation was found between the LSS "social" subscale and the "Family Income" variable $(\mathrm{p}<0.05)$. Consequently, no significant relationship was found between ASES and LSS subscales, while a significant relation was found between the age and family income variables. The reason for this can be considered that as the ages of university students increase, their orientation towards technical skills and their academic development is affected. In addition, it can be considered as the income level of university students increase, their activities such as socialization and participation in social activities are affected in a positive way and that consequently they get satisfaction.
\end{abstract}

Keywords: university students, academic self-efficacy, leisure satisfaction

\section{Introduction}

Today, with the development of technology, the value of the concept of time increases day by day in terms of increasing importance, evaluation methods and being efficient. Because individuals who make efficient use of their time are successful in both their personal lives, family lives and working performances. Therefore, the efficient arrangement of time will allow university students to fulfill their academic tasks and to achieve success and satisfaction at the level expected from them.

The concept of leisure allows individuals to be by themselves, to live their own freedom and to find themselves when used efficiently and in the correct place. Making good use of free time enables individuals to express themselves, develop their creativity, gain new experiences, improve their social environment and increase their productivity. The intelligent use of free time is a result of development and education. Leisure is valuable to the extent that it helps the development of humanity and is not used poorly (Kılbaş, 2004; Torkildsen, 1999). Leisure activities are very important because they accelerate cultural and economic development, increase working efficiency and support education and academic efficacy.

The concept of leisure satisfaction is defined as the positive emotions individuals get after meeting their individual needs with free recreational activities (Siegenthaler \& O'Dell, 1998). In addition, leisure satisfaction shows the level of satisfaction individuals perceive from leisure activities (Du Cap, 2002). The knowledge of leisure satisfaction is important in terms of being a predictor of how satisfied individuals are who participate in recreational activities, how much they are relieved from their routine and how much they are refreshed (Gökçe, 2015).

Leisure satisfaction can be considered as the perceived level of conscious or unconscious completion of the free time requirement (Demir et al., 2013). Leisure satisfaction, which also significantly affects the perception of life satisfaction of individuals or of university students (Wang et al., 2008), can play an active role in increasing the quality of life and imposing positive emotions towards it (Siegenthaler \& O'Dell, 2000). This shows that leisure activities can create 
different satisfactions (Demir \& Demir, 2014).

Leisure activities can create positive effects by providing satisfaction not only in individual activities, but also in group activities (Lloyd \& Auld, 2002). Satisfaction develops as a result of the positive perception of leisure activities (Beard \& Ragheb, 1980) and is considered as an indicator of the level of satisfaction of an individual in meeting the requirements of that individual in experiential terms (Rojek, 2013). The fact that the demographic, socio-cultural, educational, psychological and economic factors that affect leisure satisfaction vary between individuals (Esentaş, et al., 2018; Siegenthaler \& O'Dell, 2000; Iso-Ahola \& Weissinger, 1990; Yaşartürk et al., 2017) shows that the concept can include a wide range of variables.

In addition, the fact that leisure satisfaction has a positive relation with job satisfaction, motivation, quality of life, level of education and life balance (Pearson, 1998; Ragheb \& Beard, 1982; Siegenthaler \& O'Dell, 2000) makes leisure activities more important, efficient and effective in terms of the individual.

On the other hand, "Self-efficacy" is one of the fundamental concepts in Bandura's social learning theory, and Bandura (1977) defines self-efficacy as "the belief of an individual in how well they can perform the actions necessary to cope with possible situations" (Akkoyunlu \& Kurbanoğlu, 2003). In recent years, the concept of "self-efficacy" has been a frequently studied subject in the context of academic life of students (Alemdağ et al., 2014; Durdukoca, 2010; Ekici, 2012; Ferla et al., 2009; Odacı \& Çelik, 2012). Another characteristic of the gifted individuals that is affected by social comparisons and school environment is their self-efficacy beliefs. Self-efficacy includes the feelings of an individual towards their own ability, power and skills (Budak, 2003). Academic self-efficacy is defined as the belief of the individual in themselves in completing academic tasks successfully (Schunk, 2009).

The phenomenon of academic self-efficacy can be defined as the individual's opinion on their ability to regulate and perform the required actions of the course in order to achieve the determined educational performance (Zimmerman, 1995). According to Bandura (1999), the concept of self-efficacy is defined as "the self-judgment of the individual on their capacity to organize and successfully perform the necessary activities to achieve a certain performance" (Uysal, 2013).

In this context, the goals, motivation levels and academic achievements of university students affect their academic self-efficacy beliefs and improve their beliefs in achieving greater academic successes (Schunk, 2009). Compared to individuals with low self-efficacy, individuals with high self-efficacy beliefs are more eager in their learning lives, make more efforts and develop more effective strategies against difficulties (Altun \& Yazıc1, 2012; Eggen \& Kauchak, 1997). Therefore, making efficient use of leisure activities by university students will provide satisfaction and contribute to academic self-efficacy that is the basis of educational life in positive emotions.

From this point of view, the aim of this study is to examine the academic self-efficacy and leisure satisfaction levels of university students according to some variables and to determine the relationship between them. For this purpose, we tried to find answers to the following questions:

1. What are the levels of academic self-efficacy and leisure satisfaction of university students?

2. Do the academic self-efficacy and leisure satisfaction levels of university students show significant difference according to the gender, age, department and weekly free time variables?

3. Is there a significant relationship between academic self-efficacy and leisure satisfaction subscales?

\section{Method}

\subsection{The Model, Population and Sampling of the Research}

In accordance with the research objectives, "Descriptive and Relational Screening Model" was used. The population of the study consisted of 1551 university students studying at the Physical Education and Sports College of Bartın University. The sample group consisted of 1053 (642 male and 411 female) participants selected by simple random sampling method.

\subsection{Data Collection Tools}

Personal information form: It consisted of questions such as gender, age, family income level, department and weekly free time.

Academic Self-Efficacy Scale: The Academic Self-Efficacy Scale (ASES) developed by Owen and Froman (1988) and adapted to Turkish by Ekici (2012) was used to determine the academic self-efficacy of the university students who participated in the study. The scale consisted of a total of 33 items and a total of 3 subscales. The Academic Self-Efficacy Scale was prepared as a five-point likert scale as very little (1 point), little ( 2 points), relatively much (3 points), much (4 points) and quite much (5 points). The subscales of the academic self-efficacy scale are sorted as social status, cognitive practices and technical skills. In addition, the internal consistency coefficient in the general total of the Turkish validity and reliability study was found to be 0.86 . The reliability coefficients of the subscales were found to be 
0.88 in the social status subscale, 0.82 in the cognitive practices subscale and 0.90 in the technical skills subscale (Ekici, 2012). The total internal reliability coefficient within the scope of our research was determinedas 0.84 , while the reliability coefficients for the subscales were found as 0.91 in the social status subscale, 0.94 in the cognitive practices subscale and 0.83 in the technical skills subscale.

Leisure Satisfaction Scale: The "Leisure Satisfaction Scale (LSS)" developed by Beard \& Ragheb (1980-Short form) and adapted to Turkish by Gökçe \& Orhan (2011) was used. The scale has a 5-point likert scoring system and is rated between 1 "Almost Never True" and 5 "Almost Always True". In addition, the Leisure Satisfaction scale has 24 items and 6 subscales including Psychology, Education, Social, Physical, Relaxation and Aesthetics. In the validity analysis of the Turkish version of the measurement tool, findings were obtained that confirmed the six-factor structure of the scale. According to Erkuş (2005: 200), although many methods were proposed for scope validity, "the total item analysis, reliability and validity methods applied after the measurement tool is produced also prove the scope validity of the measurement tool. The internal consistency coefficient of the Leisure Satisfaction scale in the Turkish validity and reliability analysis was determined as 0.90 , while it was found as 0.77 for the psychological subscale, 0.77 for the educational subscale, 0.76 for the social subscale, 0.80 for the relaxation subscale, 0.79 for the physiological subscale and 0.79 for the aesthetic subscale. Since this finding is between the values of 0.60-0.80, which were reported to be very reliable by Alpar (2001), the LSS is reported to have an internal consistency reliability. The total internal reliability coefficient for the scope of our study was determined as 0.85 , while it was found as 0.78 for the psychological subscale, 0.76 for the educational subscale, 0.81 for the social subscale, 0.76 for the relaxation subscale, 0.81 for the physiological subscale and 0.78 for the aesthetic subscale.

\subsection{Data Analysis}

All data were analyzed through IBM SPSS Statistics 21.0 software package program. Whether the independent variables show their scales and their normal distribution Kolmogorov-Smirnov normality test was applied to investigate. The t-Test and ANOVA tests were used to analyze the differences of the participants between their satisfaction towards their leisure time activities and their academic self-efficacy levels according to their demographic characteristics; Pearson Correlation test was used to analyze the relations between the variables.

\section{Findings}

Table 1. Descriptive Statistics Results of Participants According to Demographic Variables

\begin{tabular}{|c|c|c|c|}
\hline Variables & & $\mathrm{N}$ & $\%$ \\
\hline \multirow{2}{*}{ Gender } & Female & 411 & 39.0 \\
\hline & Male & 642 & 61.0 \\
\hline \multirow{4}{*}{ Department } & Physical Education and Sports Teaching & 208 & 19.8 \\
\hline & Coaching Education & 345 & 32.7 \\
\hline & Recreation & 333 & 31.6 \\
\hline & Sports Management & 167 & 15.9 \\
\hline \multirow{6}{*}{ Weekly Free Time } & $1-5$ hours & 173 & 16.4 \\
\hline & 6-10 hours & 337 & 32.0 \\
\hline & 11-15 hours & 205 & 19.5 \\
\hline & $16-20$ hours & 122 & 11.6 \\
\hline & 21 hours and above & 216 & 20.5 \\
\hline & $\mathrm{N}$ & $x$ & SS \\
\hline Age & 1053 & 20.68 & 1.86 \\
\hline Family Income & 1053 & 2658.38 & 1170.54 \\
\hline
\end{tabular}

According to the table, the participants consisted of 411 female and 642 male university students. Of the participants, $19.8 \%$ study in Physical Education and Sports Teaching, 32.7\% in Coaching Education, 31.6\% in Recreation and 15.9\% in Sports Management. Of the participants, 173 had "1-5 hours" of weekly free time, 337 had "6-10 hours", 205 had "11-15 hours", 122 had "16-20 hours" and 216 had "21 hours and above". The average age of the participants was 20.68 , and the average family income was 2.658 TL.

Table 1. Descriptive Statistics Results of Participants According to ASES and LSS

\begin{tabular}{|c|c|c|c|c|c|c|c|}
\hline \multirow{2}{*}{ Subscales } & \multicolumn{2}{|c|}{$\mathrm{N}$} & \multirow{2}{*}{$\bar{x}$} & \multirow{2}{*}{ Median } & \multirow{2}{*}{ SS } & \multirow{2}{*}{ Min } & \multirow{2}{*}{$\operatorname{Max}$} \\
\hline & Valid Data & Missing Data & & & & & \\
\hline Social Status & 1053 & 0 & 3.53 & 3.82 & 0.910 & 1 & 5 \\
\hline Cognitive Practices & 1053 & 0 & 3.48 & 3.68 & 0.861 & 1 & 5 \\
\hline Technical Skills & 1053 & 0 & 3.47 & 3.51 & 0.911 & 1 & 5 \\
\hline Psychological & 1053 & 0 & 3.58 & 3.75 & 0.878 & 1 & 5 \\
\hline Educational & 1053 & 0 & 3.58 & 3.75 & 0.827 & 1 & 5 \\
\hline Social & 1053 & 0 & 3.61 & 3.75 & 0.880 & 1 & 5 \\
\hline Relaxation & 1053 & 0 & 3.55 & 3.51 & 0.847 & 1 & 5 \\
\hline Physical & 1053 & 0 & 3.65 & 3.75 & 0.883 & 1 & 5 \\
\hline Aesthetic & 1053 & 0 & 3.58 & 3.75 & 0.833 & 1 & 5 \\
\hline
\end{tabular}


According to the table, the median and the standard deviation of the ASES "Social Status" subscale were 3.53 and 0.910, respectively; the median and the standard deviation of the "Cognitive Practices" subscale were 3.48 and 0.861 , respectively; the median and the standard deviation of the "Technical Skills" subscale were 3.47 and 0.911 , respectively. In addition, the median and the standard deviation of the LSS "Psychological" subscale were 3.58 and 0.878 , respectively; the median and the standard deviation of the "Educational" subscale were 3.58 and 0.827, respectively; the median and the standard deviation of the "Social" subscale were 3.61 and 0.880 , respectively; the median and the standard deviation of the "Relaxation" subscale were 3.55 and 0.847 , respectively; the median and the standard deviation of the "Physical" subscale were 3.65 and 0.883 , respectively; the median and the standard deviation of the "Aesthetic" subscale were 3.58 and 0.833 , respectively.

Table 2. Two Independent Sample t-Test Results According to Gender Variable of Participants

\begin{tabular}{|c|c|c|c|c|c|c|c|}
\hline Scales & Gender & $\mathrm{N}$ & $\bar{x}$ & SS & $\mathrm{t}$ & sd & $\mathrm{p}$ \\
\hline \multirow[t]{2}{*}{ Social Status } & Female & 411 & 3.66 & .854 & \multirow{2}{*}{3.76} & \multirow{2}{*}{1051} & \multirow{2}{*}{.000} \\
\hline & Male & 642 & 3.45 & .935 & & & \\
\hline \multirow[t]{2}{*}{ Cognitive Practices } & Female & 411 & 3.58 & .819 & \multirow{2}{*}{2.96} & \multirow{2}{*}{1051} & \multirow{2}{*}{.003} \\
\hline & Male & 642 & 3.42 & .881 & & & \\
\hline \multirow{2}{*}{ Technical Skills } & Female & 411 & 3.57 & .866 & \multirow{2}{*}{2.88} & \multirow{2}{*}{1051} & \multirow{2}{*}{.004} \\
\hline & Male & 642 & 3.40 & .935 & & & \\
\hline \multirow[t]{2}{*}{ Psychological } & Female & 411 & 3.64 & .887 & \multirow{2}{*}{1.86} & \multirow{2}{*}{1051} & \multirow{2}{*}{.063} \\
\hline & Male & 642 & 3.54 & .871 & & & \\
\hline \multirow[t]{2}{*}{ Educational } & Female & 411 & 3.63 & .812 & \multirow{2}{*}{1.73} & \multirow{2}{*}{1051} & \multirow{2}{*}{.082} \\
\hline & Male & 642 & 3.54 & .834 & & & \\
\hline \multirow[t]{2}{*}{ Social } & Female & 411 & 3.68 & .881 & \multirow{2}{*}{2.02} & \multirow{2}{*}{1051} & \multirow{2}{*}{.043} \\
\hline & Male & 642 & 3.57 & .878 & & & \\
\hline \multirow{2}{*}{ Relaxation } & Female & 411 & 3.57 & .859 & \multirow{2}{*}{.60} & \multirow{2}{*}{1051} & \multirow{2}{*}{.547} \\
\hline & Male & 642 & 3.54 & .840 & & & \\
\hline \multirow[t]{2}{*}{ Physical } & Female & 411 & 3.70 & .877 & \multirow{2}{*}{1.39} & \multirow{2}{*}{1051} & \multirow{2}{*}{.163} \\
\hline & Male & 642 & 3.62 & .887 & & & \\
\hline \multirow[t]{2}{*}{ Aesthetic } & Female & 411 & 3.64 & .840 & \multirow{2}{*}{1.64} & \multirow{2}{*}{1051} & \multirow{2}{*}{.101} \\
\hline & Male & 642 & 3.55 & .828 & & & \\
\hline
\end{tabular}

According to the table, when the ASES and LSS subscales were examined according to the gender variable of the participants, statistically significant differences were found in the "Social Status", "Cognitive Practices", "Technical Skills" and "Social" subscales ( $\mathrm{p}<.05)$. When the mean values were analyzed, it was seen that this significant difference was in favor of female participants in the "Social Status", "Cognitive Practices", "Technical Skills" and "Social" subscales.

Table 3. ASES and LSS Correlation Test Results According to Age Variable of Participants

\begin{tabular}{|c|c|c|c|c|c|c|}
\hline \multirow{3}{*}{$\begin{array}{l}\text { Variable } \\
\text { Age }\end{array}$} & \multirow{2}{*}{\multicolumn{2}{|c|}{ Social Status }} & \multirow{2}{*}{\multicolumn{2}{|c|}{$\begin{array}{c}\text { Cognitive Practices } \\
-011\end{array}$}} & \multicolumn{2}{|c|}{ Technical Skills } \\
\hline & & & & & \multicolumn{2}{|c|}{$.067^{*}$} \\
\hline & Psychological & Educational & Social & Relaxation & Physical & Aesthetic \\
\hline Age & .027 & .002 & .029 & .022 & .015 & -.016 \\
\hline
\end{tabular}

\section{$*_{p}<0.05$}

According to the table, as a result of the correlation analysis to show the relationship between the age variable and the ASES subscales, while a weak and positive statistically significant correlation was found in the "Technical Skills" subscale $(\mathrm{p}<0.05)$, no significant relationship was found between the LSS subscales $(\mathrm{p}>0.05)$.

According to the table, no significant relationship was found as a result of the correlation test to show the relationship between the family income variable and the ASES subscales ( $p>0.05)$, a weak and positive statistically significant correlation was found in the LSS "Social" subscale ( $\mathrm{p}<0.05)$.

Table 5. ASES and LSS Correlation Correlation Test Results According to Family Income Variable of Participants

\begin{tabular}{lcccccc}
\hline Variable & \multicolumn{2}{c}{ Social Status } & \multicolumn{2}{c}{ Cognitive Practices } & \multicolumn{2}{c}{ Technical Skills } \\
\hline Family Income & \multicolumn{2}{c}{.045} & & .045 & & .055 \\
\hline & Psychological & Educational & Social & Relaxation & Physical & Aesthetic \\
\hline Family Income & -.039 & -.057 & $.054^{*}$ & -.022 & -.062 & -.019 \\
\hline
\end{tabular}
${ }^{*} p<0.05$ 
Table 6. ASES and LSS ANOVA Test Results According to Department Variable of Participants

\begin{tabular}{|c|c|c|c|c|c|c|c|}
\hline Scales & $\begin{array}{l}\text { Source of } \\
\text { Variance }\end{array}$ & $\begin{array}{c}\text { Sum of } \\
\text { Squares }\end{array}$ & sd & $\begin{array}{c}\text { Square } \\
\text { Average }\end{array}$ & $\mathrm{F}$ & $\mathrm{p}$ & $\begin{array}{l}\text { Significant } \\
\text { Difference }\end{array}$ \\
\hline \multirow{2}{*}{ Social Status } & Inter-group & 10.90 & 3 & 3.63 & \multirow{2}{*}{4.429} & \multirow{2}{*}{.004} & $3>1$ \\
\hline & Intra-group & 861.15 & 1049 & .82 & & & $3>2$ \\
\hline Cognitive & Inter-group & 7.90 & 3 & 2.63 & \multirow{2}{*}{3.581} & \multirow{2}{*}{.014} & \multirow{2}{*}{$1>4$} \\
\hline Practices & Intra-group & 772.32 & 1049 & .73 & & & \\
\hline \multirow[t]{2}{*}{ Technical Skills } & Inter-group & 5.62 & 3 & 2.17 & \multirow{2}{*}{2.710} & \multirow{2}{*}{.069} & \multirow[b]{2}{*}{-} \\
\hline & Intra-group & 823.18 & 1049 & .72 & & & \\
\hline \multirow{2}{*}{ Psychological } & Inter-group & 6.94 & 3 & 2.21 & \multirow{2}{*}{3.159} & \multirow{2}{*}{.053} & \multirow[b]{2}{*}{-} \\
\hline & Intra-group & 818.05 & 1049 & .76 & & & \\
\hline \multirow[t]{2}{*}{ Educational } & Inter-group & 6.79 & 3 & 2.26 & \multirow{2}{*}{3.335} & \multirow{2}{*}{.019} & \multirow{2}{*}{$1>4$} \\
\hline & Intra-group & 712.84 & 1049 & .68 & & & \\
\hline \multirow[t]{2}{*}{ Social } & Inter-group & 4.85 & 3 & 1.61 & \multirow{2}{*}{2.094} & \multirow{2}{*}{.099} & \multirow{2}{*}{ - } \\
\hline & Intra-group & 811.27 & 1049 & .77 & & & \\
\hline \multirow[t]{2}{*}{ Relaxation } & Inter-group & 7.77 & 3 & 2.59 & \multirow[b]{2}{*}{3.638} & \multirow[b]{2}{*}{.012} & $3>1$ \\
\hline & Intra-group & 747.67 & 1049 & .71 & & & $\begin{array}{l}3>2 \\
3>4\end{array}$ \\
\hline \multirow[t]{2}{*}{ Physical } & Inter-group & 6.50 & 3 & 2.16 & \multirow{2}{*}{3.095} & \multirow{2}{*}{.057} & \multirow{2}{*}{ - } \\
\hline & Intra-group & 812.76 & 1049 & .76 & & & \\
\hline \multirow[t]{2}{*}{ Aesthetic } & Inter-group & 3.66 & 3 & 1.22 & \multirow{2}{*}{1.761} & \multirow{2}{*}{.153} & \multirow[b]{2}{*}{-} \\
\hline & Intra-group & 728.04 & 1049 & .69 & & & \\
\hline
\end{tabular}

Department Groups: 1=Physical Education and Sports Teaching, 2=Coaching Education, 3=Recreation, 4=Sports Management

According to the table, a statistically significant difference was found between the department variable and the ASES "Social Status" and "Cognitive Practices" subscales $(\mathrm{p}<0.05)$. In the ASES "Social Status" subscale, this significant difference was between the "Recreation" and "Physical Education and Sports Teaching" departments and between the "Recreation" and "Coaching Education" departments and was in favor of the Recreation department ( $\mathrm{p}<.05)$. In the ASES "Cognitive Practices" subscale, the significant difference was between the "Physical Education and Sports Teaching" and "Sports Management" departments and was in favor of the Physical Education and Sports Teaching department $(\mathrm{p}<.05)$. In addition, in the LSS "Educational" subscale according to department variable, the significant difference was between the "Physical Education and Sports Teaching" and "Sports Management" departments and was in favor of the "Physical Education and Sports Teaching" department ( $\mathrm{p}<.05)$. In the LSS "Relaxation" subscale, the significant difference was between the "Recration" department and the other departments and was in favor of the "Recration" department ( $\mathrm{p}<.05)$.

Table 7. ASES and LSS ANOVA Test Results According to Weekly Free Time Variable of Participants

\begin{tabular}{|c|c|c|c|c|c|c|c|}
\hline Scales & $\begin{array}{l}\text { Source of } \\
\text { Variance }\end{array}$ & $\begin{array}{c}\text { Sum of } \\
\text { Squares }\end{array}$ & sd & $\begin{array}{c}\text { Square } \\
\text { Average }\end{array}$ & $\mathrm{F}$ & $\mathrm{p}$ & $\begin{array}{l}\text { Significant } \\
\text { Difference }\end{array}$ \\
\hline Social Status & $\begin{array}{l}\text { Inter-group } \\
\text { Intra-group }\end{array}$ & $\begin{array}{c}10.47 \\
861.58\end{array}$ & $\begin{array}{c}4 \\
1048\end{array}$ & $\begin{array}{c}2.61 \\
.82\end{array}$ & 3.186 & .013 & $2>4$ \\
\hline $\begin{array}{l}\text { Cognitive } \\
\text { Practices }\end{array}$ & $\begin{array}{l}\text { Inter-group } \\
\text { Intra-group }\end{array}$ & $\begin{array}{c}7.02 \\
753.01\end{array}$ & $\begin{array}{c}4 \\
1048\end{array}$ & $\begin{array}{l}1.60 \\
.70\end{array}$ & 2.049 & .052 & - \\
\hline Technical Skills & $\begin{array}{l}\text { Inter-group } \\
\text { Intra-group }\end{array}$ & $\begin{array}{c}10.37 \\
864.43\end{array}$ & $\begin{array}{c}4 \\
1048\end{array}$ & $\begin{array}{c}2.59 \\
.82\end{array}$ & 3.145 & .014 & $3>5$ \\
\hline Psychological & $\begin{array}{l}\text { Inter-group } \\
\text { Intra-group }\end{array}$ & $\begin{array}{c}1.673 \\
810.53\end{array}$ & $\begin{array}{c}4 \\
1048\end{array}$ & $\begin{array}{l}.41 \\
.77\end{array}$ & .541 & .706 & - \\
\hline Educational & $\begin{array}{l}\text { Inter-group } \\
\text { Intra-group }\end{array}$ & $\begin{array}{c}2.28 \\
717.36\end{array}$ & $\begin{array}{c}4 \\
1048\end{array}$ & $\begin{array}{l}.57 \\
.68\end{array}$ & .833 & .504 & - \\
\hline Social & $\begin{array}{l}\text { Inter-group } \\
\text { Intra-group }\end{array}$ & $\begin{array}{c}7.23 \\
772.90\end{array}$ & $\begin{array}{c}4 \\
1048\end{array}$ & $\begin{array}{l}1.70 \\
.73\end{array}$ & 2.243 & .044 & $5>1$ \\
\hline Relaxation & $\begin{array}{l}\text { Inter-group } \\
\text { Intra-group }\end{array}$ & $\begin{array}{c}4.21 \\
751.23\end{array}$ & $\begin{array}{c}4 \\
1048\end{array}$ & $\begin{array}{l}1.05 \\
.71\end{array}$ & 1.471 & .209 & - \\
\hline Physical & $\begin{array}{l}\text { Inter-group } \\
\text { Intra-group }\end{array}$ & $\begin{array}{c}4.42 \\
816.85\end{array}$ & $\begin{array}{c}4 \\
1048\end{array}$ & $\begin{array}{c}1.10 \\
.77\end{array}$ & 1.419 & .226 & - \\
\hline Aesthetic & $\begin{array}{l}\text { Inter-group } \\
\text { Intra-group }\end{array}$ & $\begin{array}{c}1.13 \\
730.58\end{array}$ & $\begin{array}{c}4 \\
1048\end{array}$ & $\begin{array}{l}.28 \\
.69\end{array}$ & .405 & .805 & - \\
\hline
\end{tabular}

Weekly Free Time Groups: 1=1-5 Hours, 2=6-10 Hours, 3=11-15 Hours, 4=16-20 Hours, 5=21 hours and above

According to the table, a statistically significant difference was found between the weekly free time variable and the ASES and LSS subscales $(\mathrm{p}<0.05)$. A statistically significant difference was found between the ASES "Social Status" 
and "Technical Skills" subscales according to the weekly free time variable. In the ASES "Social Status" subscale, the significant difference was between the "6-10 hours" and "16-20 hours" groups and was in favor of the "6-10 hours" group. In the ASES "Technical Skills" subscale, the significant difference was between the "11-15 hours" and "21 hours and above" groups and was in favor of the "11-15 hours" group. In the LSS "Social" subscale, the significant difference was between the "1-5 hours" and "21 hours and above" groups and was in favor of the "21 hours and above" group.

Table 8. Correlation Test Results of ASES and LSS Subscales of Participants

\begin{tabular}{lccccccc}
\hline & & Psychological & Educational & Social & Relaxation & Physical & Aesthetic \\
\hline Social Status & $\mathrm{r}$ & .024 & .002 & .007 & .006 & .007 & .001 \\
\hline Cognitive Practices & $\mathrm{r}$ & .030 & .012 & .017 & .024 & .011 & .017 \\
\hline Technical Skills & $\mathrm{r}$ & .028 & .018 & .012 & .048 & .024 & .022 \\
\hline
\end{tabular}

According to the table, no significant relationship was found in the correlation test to analyze the relationship between the ASES and LSS subscales of the participants ( $p>0.05$ ).

\section{Discussion and Conclusion}

The aim of this study was to analyze the relationship between the academic self-efficacy and leisure satisfaction levels of Physical Education and Sports College students.

According to the gender variable, when the ASES subscales were analyzed, a statistically significant difference was found in the "Social Status", "Cognitive Practices" and "Technical Skills" subscales $(\mathrm{p}<0.05)$. When the average values were examined, it was seen that the significant difference was in favor of female students. Türk (2009) found in the study conducted to analyze the academic self-efficacy of physical education and sports teachers that women had higher academic self-efficacy levels than men. In the literature, there are other studies that conclude that female students or teacher candidates had higher academic self-efficacy levels than males, supporting our study (Yelken, 2008; Yılmaz et al., 2010; Özdemir, 2008). Alemdağ et al. (2014) found in their study to analyze the academic self-efficacy and motivation of physical education and sports teacher candidates that males had higher levels of academic self-efficacy levels than females. Busch (1995) concluded in the study to analyze the academic self-efficacy and performance that males had higher self-efficacy scores than females. Similarly, there are also studies indicating that men have higher academic self-efficacy levels than women (Durdukoca, 2010; Vurucu, 2010). However, there are also studies in the literature that did not find significant differences between male and female students (Doğaner, 2017; Kavrayıcı \& Bayrak, 2016; Kılıç \& Öncü, 2014; Özsüer, 2011; Uysal, 2013; Ünlü \& Kalemoğlu, 2011; Yaşartürk et al., 2018). This shows that the studies in the literature show different results and that the female students in our sample group had higher self-confidence in their courses or academic studies, and it can be concluded that women, in the social conditions they live in, are more effective than males in learning and in applying their acquisitions in real life in terms of the social dimension. When the subscales of LSS were analyzed, a statistically significant difference was found in the "Social" subscale ( $\mathrm{p}<0.05)$, and in the same way, it was found to be in favor of female students. Çakır (2017) concluded, in the study conducted to analyze the leisure satisfaction and management of university students, that women had higher average scores than men in all LSS subscales. While Serdar \& Ay (2016) and Vong (2005) were in parallel with our study, Ardahan \& Yerlisu Lapa (2010), Ayyıldız (2015), Çelik (2011) and Kalfa (2017) reached a conclusion in favor of male students in their studies. In addition, Gökçe (2015) conducted a study on students preparing for the university entrance exam, Yiğit (2018) conducted a study on individuals participating in recreational activities in university communities and Huang (2003) conducted a study on university students studying in Taiwan, and neither of them found a significant difference in terms of the gender variable. We can say that, in the recreational area variety of the university students in our research group, women made more efficient and productive use of their leisure than men.

In the correlation analysis to analyze the relationship between the age variable and the ASES subscales, a weak and negative statistically significant correlation was found in the "Technical Skills" subscale $(p<0.05)$. Alemdağ $(2015)$ found in the study on physical education and sports teacher candidates that individuals with a mean age of 19 and below had higher academic self-efficacy than those with a mean age of 22 and above. Oğuz (2012) found in the study conducted to analyze the academic self-efficacy of class teacher candidates that older teacher candidates had higher academic self-efficacy than younger students. Considering that the average age of the university students in our research group was "20.68", we can say that it shows similarity to the studies we have referenced. Based on these results, it is possible to say that as the average age of university students increased, their success in applying technical skills in practice increased. In addition, no significant relationship was found between the age variable and the LSS subscales (p> 0.05). Similarly, Çakır (2017) found no significant difference in the study conducted to analyze the leisure satisfaction and management of university students. Serdar and Ay (2016) found in their study on university students a significant difference only in the "relaxation" subscale, but found no significant difference in the other subscales. As can be seen in the studies in the literature, it can be concluded that there is no significant relationship between age and leisure satisfaction scale due to the variety of leisure activities and the inclusion of activities for each age group. 
In the correlation analysis to analyze the relationship between the family income variable and the ASES subscales, no significant relationship was found ( $p>0.05$ ). Altun and Yazıcı (2012) concluded in the study conducted on a sample group of gifted students that family income level did not create a significant difference in academic self-efficacy. In a similar study, Alemdağ (2015) found that family income of physical education and sports teacher candidates had no effect on academic self-efficacy levels, and these results are in parallel with our research. In addition, a weak and positive statistically significant correlation was found between the family variable and the LSS "Social" subscale $(\mathrm{p}<0.05)$. This shows that university students were more satisfied with social activities that were at the center of leisure activities as their family income increased. Yiğit (2018) found in the study on individuals participating in recreational activities in university communities no significant differences in any of the subscales of the leisure satisfaction scale. Ayyldiz (2015) found in the study on the leisure satisfaction levels of individuals participating in recreational dance activities a significant difference between the "psychological" and "social" subscales. It can be concluded from this that as the socioeconomic status of the individuals taking part in recreational activities increased, the satisfaction they received from activities increased as well. Therefore, personal income or family income directly increases the orientation towards and variety of social activities and leads us to get satisfaction from leisure activities.

A statistically significant difference was found between the department variable and the ASES "Social Status" and "Cognitive Practices" subscales $(\mathrm{p}<0.05)$. When we analyzed the difference in the "Social Status" subscale, it was found that the students in the Recreation department had higher average scores than those in the Physical Education and Sports Teaching and Coaching Education departments, and this difference was significant. The reason for this reason can be explained as that the students in the Recreation department make efficient use of their leisure management within the scope of courses and take active part in social development projects and club activities in the university. In addition, when we analyzed the difference in the "Cognitive Practices" subscale, it was found that the students in the Physical Education and Sports Teaching department had higher average scores than those in the Sports Management department. Kılı̨ and Öncü (2014) found no significant differences between the departments in their study conducted to determine the metacognitive learning strategies and academic self-efficacy levels of physical education and sports college students. As the reason for the difference in our research, it is known that the Physical Education and Sports Teaching department is the first preferred department in the Physical Education and Sports College entrance exams. For this reason, the fact that the students entering the Physical Education and Sports Teaching department have higher scores raises awareness in areas such as participation in the class, regular note-taking and expressing their opinions on subjects and preparation. This directly affects cognitive practices and can be explained as the reason of the significant difference with the students in the sports management department. A statistically significant difference was found between the department variable and the LSS "Educational" and "Relaxation" subscales $(\mathrm{p}<0.05)$. When we look at this difference, there was also a significant difference between the Physical Education and Sports Teaching and Sports Management departments in the "Educational" subscale. Students reaching the highest scores in the university entrance exam generally prefer the Physical Education and Sports Teaching department, so we may state the reason for the significant difference considering that they are involved more in activities with educational content and that can contribute to their courses compared to the Sport Management department in terms of participation in leisure activities. In addition, in the "Relaxation" subscale, a statistically significant difference was found between the students in the Recreation department and the other departments in the Physical Education and Sports College (Physical Education and Sports Teaching, Coaching Education and Sports Management). The reason for the difference in the "Relaxation" subscale with the other departments may be due to the fact that the undergraduate courses in the recreation department are on making efficient, productive and accurate use of leisure activities.

A statistically significant difference was found between the weekly free time variable and the ASES "Social Status" and "Technical Skills" subscales, which was in favor of the students with insufficient weekly free times. The concept of social status includes activities not including socializing, but including preparation and participation in courses. Therefore, the reason for the significant difference can be explained as that university students do researches in the library regarding personal development and courses and focus on technical information in their free time. Since it is thought that students studying in the same education program and who have more weekly free time would participate in sportive, entertainment and relaxation activities in their free time, it may be considered that they may be lacking in social status and technical skills compared to those with less weekly free time. A statistically significant difference was found between the weekly free time variable and the LSS "Social" subscale. This difference was found between students with weekly free times of "20 hours and above" and "1-5 hours". Çakır (2017) showed similarity in the study on the leisure satisfaction of university students, and found a significant difference in the "Social" subscale. University students prefer various activities in their free times. Especially, as the time increases, the variety of activities and the level of satisfaction provided increase in parallel. Therefore, the university students with more free time will participate in social activities with higher leisure satisfaction levels and will provide satisfaction.

In conclusion, no significant relationship was found between the ASES and LSS subscales, while a significant 
relationship was found between the age and family income variables. The reason for this can be stated as that as the ages of the university students increase, their orientation towards technical skills regarding their courses increases and they will experience academic development. In addition, family income, which is feature that can increase the variety of leisure activities of university students, is decisive. Therefore, we can say that as the incomes level of the university students increase, their activities such as socialization and participation in social activities will progress in a positive way, and consequently they will get satisfaction.

\section{References}

Akkoyunlu, B., \& Kurbanoğlu, S. (2003). A study on teacher candidates perceived information literacy self-efficacy and perceived computer self-efficacy. Hacettepe University Journal of Education, 24(24), 1-10. Retrieved from http://dergipark.ulakbim.gov.tr/hunefd/article/view/5000048750

Alemdağ, C. (2015). Pre-service physical education teachers' epistemological beliefs, academic selfefficacy and learning approaches. Master Thesis. Karadeniz Technical University, Institute of Educational Sciences, Trabzon.

Alemdağ, C., Öncü, E., \& Yılmaz, K. A. (2014). Preservice physical education teachers' academic motivation and academic self-efficacy. Hacettepe Journal of Sport Sciences, 25(1), 23-35. https://doi.org/10.17644/sbd.171304

Alpar, R. (2001). Spor bilimlerinde uygulamalı istatistik. Ankara: Nobel Yayın Dağıtım. [Turkish]

Altun, F., \& Yazıc1, H. (2012). Self-concept and academic self-efficacy beliefs of gifted students: a comparative study. Mehmet Akif Ersoy University Journal of Faculty of Education, 1(23), 319-334. Retrieved from http://dergipark.gov.tr/maeuefd/issue/19396/206053

Ardahan, F., \& Lapa, T. Y. (2010). An examination of leisure satisfaction level of university students with regard to gender and income. Hacettepe Journal of Sport Sciences, 21(4), 129-136. Retrieved from http://dergipark.gov.tr/sbd/issue/16387/171397

Ayyıldız, T. (2015). Examination of leisure satisfaction levels of individuals participating in recreative dance activities. Master Thesis. Gazi University, Institute of Health Sciences, Ankara.

Bandura, A. (1977). Self-efficacy: Toward a unifying theory of behavioral change. Psychological Review, 84(2), 191-215. https://doi.org/10.1037/0033-295X.84.2.191

Bandura, A. (1999). Social cognitive theory: An agentic perspective. Asian Journal of Social Psychology, 2(1), 21-41. https://doi.org/10.1111/1467-839X.00024

Beard, J. G., \& Ragheb, M. G. (1980). Measuring leisure satisfaction. Journal of Leisure Research, 12(1), 20-33. https://doi.org/10.1080/00222216.1980.11969416

Budak, S. (2003). Psikoloji sözlü̈̆̈̈. Ankara: Bilim ve Sanat Yayınları. [Turkish]

Busch, T. (1995). Gender differences in self-efficacy and academic performance among students of business administration. Scandinavian Journal of Educational Research, 39(4), 311-318. https://doi.org/10.1080/0031383950390403

Çakır, O. V. (2017). The relationship between university students' leisure satisfaction levels and leisure management. Gaziantep University Journal of Sport Sciences, 2(3), 17-27. Retrieved from http://dergipark.gov.tr/gaunjss/issue/31075/331319

Çelik, G. (2011). Analyse leisure constraints and satisfaction of disabled people working in public sector (Antalya Center Sample). Master Thesis. Akdeniz University, Institute of Social Sciences, Antalya.

Demir, M., \& Demir S. Ş. (2014). Employees' leisure time requirements and the factors affecting leisure time satisfaction. İşletme ve İktisat Çalışmaları Dergisi, 2(3), 74-84. Retrieved from http://dergipark.gov.tr/iicder/issue/31645/347020

Demir, Ş. Ş., Yeşiltepe, B., \& Demir, M. (2013). The comparison of leisure time evaluation and perceptions of hotel managers and public institutions' managers. Akademik Baklş Uluslararası Hakemli Sosyal Bilimler Dergisi, 39, 1-17. Retrieved from http://dergipark.gov.tr/abuhsbd/issue/32923/36575

Doğaner, S. (2017). The effect of regular exercise program on individuals' stress, happiness, and leisure satisfaction levels. PHD Thesis. Ankara University, Institute of Health Sciences, Ankara.

Du Cap, M. C. (2002). The perceived impact of the acadia advantage program on the leisure lifestyle and leisure satisfation of the students at acadia university. Unpublished Master Thesis. Acadia University, Ottowa.

Durdukoca, F. Ş. (2010). Analysis of academic self-efficiency beliefs of elementary school teacher candidates using different variables. Abant İzet Baysal University Journal of Faculty Education, 10(1), 69-77. Retrieved from 
http://dergipark.gov.tr/aibuefd/issue/1498/18125

Eggen, P., \& Kauchak, D. (1997). Educational psychology windows on classrooms (3rd Ed.). New Jersey: Prentice-Hall Inc.

Ekici, G. (2012). Academic self-efficacy scale: The study of adaptation to Turkish validity and reliability. Hacettepe University Journal of Education, 43(43), 174-185. Retrieved from http://dergipark.gov.tr/hunefd/issue/7795/102022

Erkuş, A. (2005). Bilimsel araştırma sarmalı. Ankara: Seçkin Yayıncılık. [Turkish]

Esentaş, M., Güzel, P., Yıldız, K., \& Çokşen, M. (2018). The role of the qality of life of the participation to the time leisure time activities in nursing room. Journal of Physical Education \& Sports Science, 12(3), 235-241.

Ferla, J., Valcke, M., \& Cai, Y. (2009). Academic self-efficacy and academic self-concept: Reconsidering structural relationships. Learning and Individual Differences, 19(4), 499-505. https://doi.org/10.1016/j.lindif.2009.05.004

Gökçe, H. (2015). Determine the effect of recreational activities on students' studying for university entrance exam self-efficacy, test anxiety, and leisure time satisfaction level. PHD Thesis. Institute of Health Sciences, Ankara University, Ankara.

Gökçe, H., \& Orhan, K. (2011). Validity and reliability study of the leisure satisfaction scale (LSS) into Turkish. Hacettepe Journal of Sport Sciences, 22(4), 139-145. https://doi.org/10.17644/sbd.171376

Huang, C. Y. (2003). The relationships among leisure participation. leisure satisfaction, and life satisfaction of college students in Taiwan. PHD Thesis. University of the Incarnate Word, Faculty of the Graduate School.

Iso-Ahola, S. E., \& Weissinger, E. (1990). Perceptions of boredom in leisure: conceptualization, reliability, and validity of the leisure boredom scale. Journal of Leisure Research, 22(1), 1-17. https://doi.org/10.1080/00222216.1990.11969811

Kalfa, S. (2017). To examine the life satisfaction and leisure time satisfaction levels of the students of sport sciences and education faculty in terms of different variables (Uşak University Sample). Master Thesis. Muğla Sttkı Koçman University, Institute of Social Sciences, Muğla.

Kavrayıc1, C., \& Bayrak, C. (2016). Preservice teachers' sense of self efficacy. Adlyaman University Journal of Institute of Social Sciences, (23), 623-658. https://doi.org/10.14520/adyusbd.70805

Kılbaş, Ş. (2004). Rekreasyon boş zamanı değerlendirme. (3rd edition). Ankara: Nobel Yayınevi. [Turkish]

Kılıç K. S., \& Öncü, E. (2014). Metacognitive learning strategies and academic selfefficacy of physical education and sport school students. Journal of Sports and Performance Researches, 5(2), 13-22. https://doi.org/10.17155/spd.31708

Lloyd, K. M., \& Auld, C. J. (2002). The role of leisure in determining quality of life: Issues of content and measurement. Social Indicators Research, 57(1), 43-71. https://doi.org/10.1023/A:1013879518210

Odacı, H., \& Çelik, Ç. B. (2012). Relationship between university students' problematic internet use and their academic self-efficacy, academic procrastination, and eating attitudes. e-Journal of New World Sciences Academy, 7(1), 389-403. https://doi.org/10.12739/10.12739

Oğuz, A. (2012). Academic self-efficacy beliefs of prospective primary school teachers. Anadolu Journal of Educational Sciences International, 2(2), 15-28. Retrieved from http://dergipark.gov.tr/ajesi/issue/1527/18740

Owen, V. S., \& Froman, D. R. (1988). Development of a college academic self-efficacy scale. Paper presented at the annual meeting of the national council on measurement in education, New Orleans, LA.

Özdemir, M. S. (2008). An investigation of prospective primary teachers' self-efficacy beliefs regarding teaching process in terms of certain variables. Educational Administration: Theory and Practice, 54(54), 277-306. Retrieved from http://dergipark.gov.tr/kuey/issue/10343/126709

Özsüer, S., İnal, G., Uyanık, Ö., \& Ergün, M. (2011). Investigation academic self-efficacy belief levels of students being taught at Afyon Kocatepe University. Afyon Kocatepe University Journal of Social Sciences, 13(2), 113-125.

Pearson, Q. M. (1998). Job satisfaction, leisure satisfaction, and psychological health. The Career Development Quarterly, 46(4), 416-426. https://doi.org/10.1002/j.2161-0045.1998.tb00718.x

Ragheb, M. G., \& Beard, J. G. (1982). Measuring leisure attitude. Journal of Leisure Research, 14(2), 155-167. https://doi.org/10.1080/00222216.1982.11969512

Rojek, C. (2013). Capitalism and leisure theory (Routledge Revivals). NY: Routledge. 
Schunk, D. H. (2009). Öğrenme teorileri: eğitimsel bir bakışla (tr. Muzaffer Sahin). (5th edition), Ankara: Nobel Akademik Yayınc1lık. ISBN: 9786051330693

Serdar, E., \& Ay Mungan, S. (2016). A study on university students' satisfaction levels and perceived degree of freedom in relation to their mode of participation in leisure activities. The Journal of Social Science, 9, 365-374.

Siegenthaler, K. L., \& O'Dell, I. (1998). Meeting the leisure needs of families. Journal of Parks and Recreation, 33(12), $38-43$.

Siegenthaler, K. L., \& O'Dell, I. (2000). Leisure attitude, leisure satisfaction, and perceived freedom in leisure within family dyads. Leisure Sciences, 22(4), 281-296. https://doi.org/10.1080/01490409950202302

Torkildsen, G. (1999). Leisure and recreation management. London, UK: Spon Pres.

Türk, N. (2009). Physical education and sports teacher's self efficacy of their jobs (Nevşehir City Model). Master Thesis. Niğde University, Institute of Social Sciences, Niğde.

Ünlü, H., \& Kalemoğlu, Y. (2011). Academic self-efficacy of Turkish physical education and sport school students. Journal of Human Kinetics, 27, 190-203. https://doi.org/10.2478/v10078-011-0015-z

Uysal, İ. (2013). Academicians' general self efficacy beliefs: AIBU faculty of education case. Trakya University Journal of Education, 3(2), 144-151. Retrieved from http://dergipark.gov.tr/trkefd/issue/21474/230174

Vong, T. N. (2005). Leisure satisfaction and quality of life in Macao, China. Leisure Studies, 24(2), 195-207. https://doi.org/10.1080/02614360412331313502

Vurucu, F. (2010). Meslek lisesi öğrencilerinin meslek seçimi yeterliliği ve meslek seçimini etkileyen faktörler. Master Thesis. Yeditepe University, Institute of Social Sciences, İstanbul.

Wang, E. S. T., Chen, L. S. L., Lin, J. Y. C., \& Wang, M. C. H. (2008). The relationship between leisure satisfaction and life satisfaction of adolescents concerning online games. Adolescence, 43(169), 177-184.

Yaşartürk, F., Akyüz, H., \& Karataş, İ. (2017). Examination of university students' levels of leisure boredom perception and life satisfaction towards recreative activities. International Journal of Cultural and Social Studies (IntJCSS), 3(Special Issue), 239-252. Retrieved from http://dergipark.gov.tr/intjcss/issue/33182/369780

Yaşartürk, F., Akyüz, H., Karataş, I., \& Türkmen, M. (2018). The relationship between free time satisfaction and stress levels of elite-level student-wrestlers. MDPI-Education Sciences, 8(3), 133-143. https://doi.org/10.3390/educsci8030133

Yelken, K. (2008). The factories of middle education last class student university selection and occupation selection: Example for Sakarya. Master Thesis. Sakarya University, Institute of Social Sciences, Sakarya.

Yiğit, İ. (2018). Üniversite topluluklarında rekreatif faaliyetlere katılan bireylerin serbest zaman tatmin düzeylerinin incelenmesi. Master Thesis. Institute of Health Sciences, İnönü University, Malatya.

Yılmaz, G., Yılmaz, B., \& Türk, N. (2010). Over-graduate thesis physical education and sports teacher's self efficacy of their jobs (Nevşehir City Model). Selçuk University Journal of Physical Education and Sport Science, 12(2), $85-90$.

Zimmerman, B. J. (1995). Self-efficacy and educational development. In: A. Bandura (Ed.) Self- Efficacy in Changing Societies, Cambridge University Press. https://doi.org/10.1017/CBO9780511527692.009

\section{Copyrights}

Copyright for this article is retained by the author(s), with first publication rights granted to the journal.

This is an open-access article distributed under the terms and conditions of the Creative Commons Attribution license which permits unrestricted use, distribution, and reproduction in any medium, provided the original work is properly cited. 